\title{
The vehicle approach for freight road transport energy and environmental analysis in Spain
}

\author{
P. J. Pérez-Martínez
}

Received: 1 September 2008 / Accepted: 29 April 2009/Published online: 13 May 2009

(C) European Conference of Transport Research Institutes (ECTRI) 2009

\begin{abstract}
Purpose and methodology This paper summarizes the results of a permanent road freight sample survey carried out in 19972003 on heavy duty vehicles in Spain. In particular, this work reviews some of the key indicators that are measuring the efficiency and the operational performance of the freight road transport. The indicators of transport are coming directly and indirectly from the survey. The survey is based on a stratified random sampling, and represents an audit of the performance of 41,600 vehicles in a yearly basis.

Main results Although the study shows wide variation in absolute values between 1997 and 2003, energy and environment efficiencies improve by $0.2 \%$.

Conclusions Nevertheless, assumptions and analyses of freight road transport in Spain find significant new points of view to the problems in order to assess vehicle utilization, fuel efficiency and $\mathrm{CO} 2$ emissions.
\end{abstract}

Keywords Vehicle approach · Performance indicators · Environmental efficiency $\cdot$ Spain

\section{Introduction}

Freight transport grows in Spain as a result of the economical development on expenses exclusively of road; on the other hand, rail and other alternative transport modes do not take up this development. Though there have been environmental improvements due to technology of new

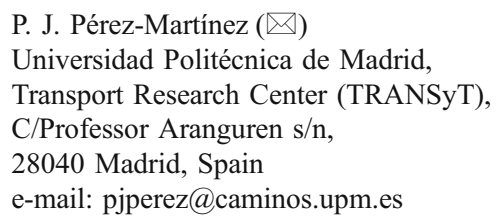

road transport vehicles, there has also been a steady deterioration of environmental standards (i.e. air quality) on many interurban roads [1].

The willingness to apply restraints on freight road transport is likely to be limited to economical markets and business spots for which rail or other alternative transport modes can provide a reasonable alternative to road [2]. However, in Spain origins and destination are fairly dispersed, and therefore rail is not a good alternative to road in many cases.

The major concern to be faced today is to determine opportunities for improving transport efficiency of freight road. It lies between, on the one hand, improving energy and environment efficiencies on freight road transport to cater for the demands for which other transport modes are not realistic alternatives and, on the other hand, developing new forms of freight transport [3].

This concern is not restricted to the Spanish freight sector and questions for research on freight transport, energy consumption and $\mathrm{CO}_{2}$ emissions have been discussed by researchers in different contexts [4-7]. Developed countries' data and results of inter-mode and inter-country comparisons are available from institutions such as Organization of Economic Cooperation and Development-OECD [8, 9], European Conference of Ministers of Transport-ECMT [10] and European Environmental Agency-EEA [11].

Existing studies give some evidence of how to perform road freight energy analysis from different perspectives and approaches [12, 13]. One of the possible approaches involves using national statistics and analyzing them with a vehicle oriented perspective. This paper investigates energy and environmental efficiencies of the Spanish market using the permanent road freight vehicle survey. The paper defines the vehicle approach and its main method and presents results related to the vehicle survey. 
The paper reviews the main developed methodologies for this topic of existing studies and compares the results of road freight vehicle statistics and data in Spain with other countries. The paper draws some conclusions relating to data need for future road freight vehicle surveys and gaps in knowledge concerning data and understanding. Finally, the paper evaluates potential measures to improve energy and emissions efficiencies and impacts on key transport performance indicators.

\subsection{Freight transport in Spain, Gross Domestic Product (GDP) and energy consumption}

Transport supports the economical development of Spain and contributed to $5.3 \%$ of GDP in 2003 (3\% road transport alone). Transport has a multiplying effect over other sectors and employed $4.7 \%$ of working people in 2003 (3.2\% road transport alone). Freight transport in Spain carried 400,985 millions tonne-kilometers in 2003 and is dominated by road with a share of $84.5 \%$ [14]. Figure 1 shows freight transport and GDP trends. During 1990-1995 period, the growth of freight transport has closely followed the growth of GDP; later on, the growth of freight transport was higher than the growth of GDP due to several factors: globalization of economic and industrial activities, new technologies and innovations in the productive system and logistics ("just in time"), and unification of the European market [15]. Freight transport grew 61\% during the period 1990-2003 at an average annual rate of $3.7 \%$; increments of GDP for the same period were $40 \%$ and $2.6 \%$. Therefore, it seems that the coupling will continue well into the twenty-first century. Rapid freight transport growth can bring many environmental risks and problems that can seriously jeopardize the sustainability of the transport system [2].

Transport consumes around $36 \%$ of the total energy consumption in Spain. Therefore, future scenarios foresee a steady increment of this share: $37.8 \%$ (2006) and 38.9\%

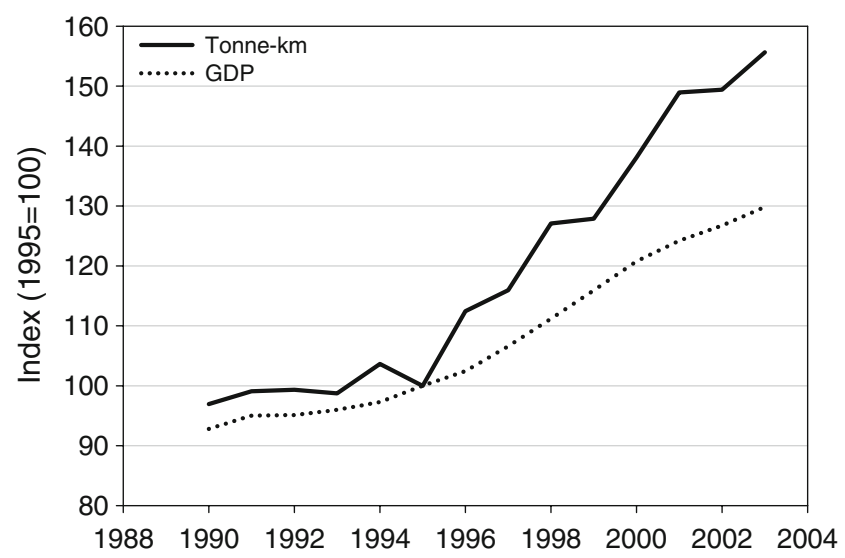

Fig. 1 Freight transport demand and GDP in Spain
(2012) [16]. In 2003, transport used 1,863,281 terajoules $\left(10^{12}\right.$ joules) (69\% road transport alone). The share of road freight transport to total energy consumption in Spain is $14 \%$ and Heavy Duty Vehicles (HDV) contribute to $34 \%$ of the total road transport energy consumption, 437,126 terajoules. Transport energy use will grow exponentially in Spain in the next years at least that transport activity and GDP could be decoupled [8,9].

\section{Methodology}

\subsection{Permanent road freight sample surveys}

The Spanish Ministry of Development (SMD) developed a large-scale Permanent Road Freight Sample Survey (PRFSS) in 1992 to describe freight transport performance in Spain and to provide an in-depth view into the use and efficiency of the Spanish road freight fleet. Updated surveys are undertaken every year since 1992. The results of the surveys are summarized in an annual report [17]. All the surveys employ the same methodology, and the same set of descriptive (DIs) and key performance indicators (KPIs) to compare results from year to year.

DIs are measures of national indices (DIs). KPIs are measures of utilization indices (of "input usage" expressed as a ratio of the actual input of sources to some normative value), production indices (of "transformational efficiency" expressed as input/output ratio) and effectiveness indices (of quality of process output expressed as a ratio of the actual quality achieved to some norm).

The main objectives of the PRFSS are to:

- know, through sampling of freight transport operations on HDV, the flows that measure the degree of sector's activity and load factors,

- benchmarking of freight transport efficiency and operational performance,

- estimates levels of efficiency assessing the potential for improving the efficiency of delivery operations yielding significant savings in fuel and $\mathrm{CO}_{2}$ emissions.

To achieve these objectives, PRFSS measures transport operations in terms of efficiency and operational performance on a consistent basis broadly accepted by other EU countries. PRFSS collects data over a one year period recording it in a specially constructed form developed by a Spanish panel of transport experts.

Similar surveys to PRFSS are made in other European countries. These surveys share a common methodology recommended by Eurostat in order to harmonize and compare EU road freight statistics [18, 19]. For instance, Great Britain, France and Germany perform the "Continuing Survey of Road Goods Transport/CSRGT" [20], "Transport Routier de 
Marchandises/TRM" [21] and "Kraftfahr-Bundesamt/KBA" [22] respectively. All these surveys provide annual data about road freight operations carried out by goods vehicles with a loading capacity above 3.5 tonnes or maximum permissible laden weight above 6.0 tonnes.

\subsection{Description of the survey}

The PRFSS is directed to Spanish HDV bigger than 3.5 tonnes and is included in the National Statistical Plan following the EU directives $78 / 546$ and $89 / 462$. The PRFSS is directed to Spanish companies, fleets and vehicles, and the results of the survey do not include the segment of international road transport trucks entering Spain. Unfortunately, the PRFSS does not provide data from other country's PRFSSs relating road freight transport activities. A random stratified sampling is used and the statistical sampling unit is vehicle per week (truck or tractor), (i.e. the powered vehicle and its potential trailer during one week). The database used to take the random sample is the total population of Spanish HDV operating in Spain and abroad (349,348 vehicles in 2003). The stratification criteria are:

- public haulage (hire) or private services (own account),

- national (transport between and within municipalities) or international trips,

- loading capacity, 3.5-10, 10.1-18 and bigger than 18 tonnes.

Results estimation procedure is done for each 4-5 weeks period, over a sampling of 800 vehicles per week (52 weeks, 41,600 vehicles per year), using an expansion stratified estimator corrected for the vehicles that not correspond to the survey and fails [23]. The strata are not sampled at the same rate as there are large differences in the population of each strata. Consequently, the size of sampling in each strata is done using the minimum variance criteria. A substitute sampling of 200 vehicles per week is considered to keep the effective sampling. The analysis is performed using the random stratified sampling procedure in SAS statistical software [24]. The methods used by PRFSS in compiling the data involve sample methodology which measures the quality of the survey. The percentage standard error $(95 \%$ confidence) of the annual estimates for tonnes transported, tonne-kilometres performed and total kilometers travelled loaded for total goods road transport and for national goods road transport shall not be greater than $\pm 5 \%$ [18].

Estimations are calculated in each strata and expanded to the total population. For each strata $h$, the estimator is the following:

$$
\widehat{X}_{h}=\sum_{i=1}^{n h} F_{h} x_{h i}
$$

where:

$F_{h}=\frac{N_{h}\left(1-\frac{b_{(t i t) h}+e_{(t i t) h}}{800 \widehat{x}_{h} s}\right)}{\mathrm{n}_{\mathrm{h}}^{\prime}} \widehat{x}_{h} \mathrm{~S}$

being:

$x_{h i} \quad$ Value of $X$ variable in vehicle $i$ of strata $h$

$\mathrm{F}_{h} \quad$ Expansion coefficient for strata $h$

$\mathrm{n}_{\mathrm{h}} \quad$ Number of sampling vehicles from strata $h$

$N_{h} \quad$ Total number of authorized vehicles from strata $h$

$b_{(t i t) h} \quad$ Number of fails detected in the sampling within strata $h$

$e_{(t i t) h} \quad$ Number of vehicles within strata $h$ that not correspond to the survey (fireman, forestry, construction trucks, snowplows, etc.)

S Number of weeks within the calculation period.

Having committed themselves to the survey, companies, fleets and vehicles were asked to submit a survey questionnaire form by post. The companies had the responsibility of the correct submission of the questionnaire form. The questionnaire form was published elsewhere together with the definitions and methods of collecting and recording the information [17]. In order to deal with seasonality matters, the PRFSS is continuous and the questionnaires are sent regularly to vehicle users.

\subsection{Vehicle descriptive and key performance indicators}

The use of DIs and KPIs to monitor efficiency and to assess operational performance of freight transport is not specific for Spain and has been widely discussed in previous studies [25-27]. These studies are related to the wider impact of road freight transport operations on the environment and their metrics are not concerned exclusively with economic efficiency. Based on these previous studies, this paper compiles a list of DIs and KPIs.

Some of the indicators used in this study are measured directly by the PRFSS and some of them are estimates (Table 1). There are KPIs that measure utilization, production and effectiveness directly, such us empty running operations and kilometers, vehicle loading, and vehicle time utilization. Empty running, expressed in terms of kilometers or operations, is the distance or operations the vehicle travelled empty. Vehicle loading is the ratio of the actual load carried to the maximum load that could have been carried within vehicle weight, deck area and height constraints. Vehicle loading measures the use of total weight capacity. It is, however, often the volume or deck space of the lorry that sets the limit on what can be carried. Therefore, decreasing vehicle loadings may also reflect 
Table 1 Descriptive (DIs) and key performance indicators (KPIs) of road freight transport

${ }^{1}$ DIs: descriptive indicators,

KPIs: performance indicators

${ }^{2}$ PRFSS: Directly measured by the Permanent Road Freight Sample Survey, E: estimates

${ }^{3}$ Estimated from the running kilometres considering an average consumption of $0.25-0.35 \mathrm{l} / \mathrm{km}$; information is based on

McKinnon [26], Leonardi

[29] and Mataix [30]

${ }^{4}$ Estimated from fuel consumption using the equivalences of 41.87 petajoules $\left(10^{15}\right.$ joules $)$ per mtoe $\left(10^{6}\right.$ toe $)$ and 38.66 megajoules $\left(10^{6}\right.$ joules $)$ per litre of diesel

${ }^{5}$ Estimated from toe using the equivalence of 0.345 mtoe per $\mathrm{mtCO}_{2} \mathrm{e}\left(10^{6} \mathrm{tCO}_{2} \mathrm{e}\right)$, IEA [31]

${ }^{6}$ Estimated using Eq. 3

${ }^{7}$ Estimated using Eq. 4

${ }^{8}$ Estimated using Eq. 5

\begin{tabular}{|c|c|c|c|c|}
\hline Type $^{1}$ & Indicator name & Units & Measure of & Source $^{2}$ \\
\hline \multirow[t]{10}{*}{ DIs } & Fleet & number & National Index & PRFSS \\
\hline & Operations & number & National Index & PRFSS \\
\hline & Vehicle kilometres & vkm & National Index & PRFSS \\
\hline & Running kilometres & $\mathrm{km}$ & National Index & PRFSS \\
\hline & Tonnes & $\mathrm{t}$ & National Index & PRFSS \\
\hline & Tonne kilometres & $\mathrm{tkm}$ & National Index & PRFSS \\
\hline & Load capacity & $\mathrm{t}$ & National Index & PRFSS \\
\hline & Fuel consumption & 1 & National Index & $\mathrm{E}^{3}$ \\
\hline & Tonnes oil equivalent & toe & National Index & $E^{4}$ \\
\hline & Tonnes of $\mathrm{CO}_{2}$ equivalent & $\mathrm{tCO}_{2} \mathrm{e}$ & National Index & $E^{5}$ \\
\hline \multirow[t]{10}{*}{ KPIs } & Empty running operations & $\%$ & Energy Intensity & PRFSS \\
\hline & Empty running kilometres & $\%$ & Energy Intensity & PRFSS \\
\hline & Vehicle loading & $\%$ & Energy Intensity & PRFSS \\
\hline & Operation factor & $\mathrm{km} /$ operation & Energy Intensity & $\mathrm{E}$ \\
\hline & Fuel efficiency & $1 / \mathrm{kmor}$ koe $/ \mathrm{tkm}$ & Energy Intensity & $\mathrm{E}$ \\
\hline & Emission efficiency & gr $\mathrm{CO}_{2} / \mathrm{tkm}$ & Energy Intensity & $\mathrm{E}$ \\
\hline & Vehicle time utilization & $\%$ & Production & PRFSS \\
\hline & Transport content & $\mathrm{km} / \mathrm{t}$ & Production & $E^{6}$ \\
\hline & Transport distance & $\mathrm{km}$ & Logistical reach & $E^{7}$ \\
\hline & Transport efficiency & $\mathrm{tkm} / \mathrm{vkm}$ & Organization & $E^{8}$ \\
\hline
\end{tabular}

a change in what is being transported by specific modes [11]. Vehicle time utilization, expressed as the average percentage of operability, is the trailer time running on the road: loading/unloading, awaiting unloading/uploading, pre-load (excluding maintenance/repair, rest period or idle).

The PRFSS indicators are designed to measure operations rather than performance. To compensate this imbalance, new KPIs are adopted: transport content, transport distance and transport efficiency. These three indicators are strongly correlated to environmental and other societal impacts. These three indicators relate transport to production (transport content), logistical reach (transport distance) and specific organization (transport efficiency). Therefore, the last two are also linked with aspects related to transport growth [28].

The transport content is the ratio between the average length of haul and the average payload, and is measured in kilometers per tonne:

transport content $=\frac{\text { average length of haul }}{\text { average payload }}=\frac{\text { kilometers }}{\text { tonne }}$

The transport distance is the ratio between tonne kilometers and the payload:

transport distance $=\frac{\text { tonne }- \text { kilometers }}{\text { payload }}$
As an indicator of transport efficiency, the average payload can be computed as the ratio between the tonne kilometers and the vehicle kilometers:

transport efficiency $=\frac{\text { tonne }- \text { kilometers }}{\text { vehicle }- \text { kilometers }}$

Road freight transport has negative environmental impacts such as energy consumption, carbon dioxide $\left(\mathrm{CO}_{2}\right)$ and pollution emissions. For this reason, new indicators relate to the wider impacts of transport operations on the environment are defined: fuel and energy consumption, expressed in liters or tonnes of oil equivalent (toe), and $\mathrm{CO}_{2}$ emissions, expressed in tonnes of $\mathrm{CO}_{2}$ equivalent $\left(\mathrm{tCO}_{2} \mathrm{e}\right)$. Table 1 shows the equivalences used for the calculation of these indicators from the running kilometers. These equivalences make possible to estimate the environmental impacts of transport using fuel and emission efficiency indicators [29]. Given that the PRFSS has no data on energy consumption, fuel consumption average values of 0.25 to 0.35 (liters per kilometer, depending of vehicle size) were considered assuming that road transport operations monitored in other European studies $[26,29,30]$ are representative of the general movement of goods by road in Spain. The transport energy performance indicator, defined as fuel efficiency, has been converted to emission efficiency with the main unit gram $\mathrm{CO}_{2}$ emitted per tonne-kilometre ( $\left.\mathrm{gr} \mathrm{CO}_{2} / \mathrm{tkm}\right)$. 


\section{Survey results}

\subsection{Vehicle approach}

The PRFSS stratifies the vehicles into homogeneous groups, in relation to their size, service type and logistical reach:

- vehicle size: small rigid ( 2 axles and $<10$ tonnes), medium rigid ( 2 axles and 10-18 tonnes), large rigid ( $>2$ axles and $>18$ tonnes), tractor (32 tonnes articulated vehicles and 4 axles), and tractor (3844 tonnes articulated vehicles and $>4$ axles),

- service type: private service when the vehicle is used exclusively for the transport of own account goods, without a payment, and public haulage service when the vehicle is used for the transport of other's goods in concept of a payment (hire or reward),

- logistical reach: linked with legal operating authorization depending if the vehicle circulates within the same municipality, between close municipalities or circulates in a bigger area at a national or international level.

Figure 2 shows the distribution of five DIs (tonnes, tonne kilometers, number of operations, load capacity and number of vehicles), into category classes according to service and vehicle size. $91 \%$ of total tonne kilometers, $73 \%$ of tonnes, and $64 \%$ of operations are made by public service. Therefore, $63 \%$ of vehicles are devoted to public service operations. This gives the importance of the public service over the private service especially in longdistance operations. Therefore, public service is using bigger and newer vehicles than private service and its load capacity is three times bigger. Looking at the distribution of the vehicles according with their size, $42 \%$ of vehicles are tractors and $29 \%$ are small rigid vehicles. Tractors transport $60 \%$ of tonnes and produce $87 \%$ of tonne kilometers. Tractors with a share of $64 \%$ of total load capacity are involved only in $39 \%$ of operations. Smaller vehicles are devoted to short-distance operations and urban freight activities. There is a correlation between public service dominance and tractor dominance.

Table 2 presents absolute values of previous DIs together with data on vehicle loading (loaded operations and total operations), empty running (operations and kilometers), and vehicle time utilization. There are no big differences between public and private services concerning KPIs except vehicle time utilization. Small rigid vehicles present lower values of vehicle loading (both loaded and total operations) and empty running (both operations and kilometers) than other vehicle types. Opposite, small rigid vehicles use better the time than the other vehicles. Tractors have the highest values of vehicle loading but similar low values of empty running operations and kilometers to small rigid vehicles.

Vehicle time utilization varies from 71 to $82 \%$ depending on service and vehicle type (Table 2). The lowest value of vehicle time utilization belongs to large rigid vehicles.

\section{Main results}

Results of DIs and KPIs are summarized in Table 3 for years 2003 and 1997 together with their annual increments. All DIs have experienced increments being the most significant ones: tonnes, running kilometers and operations. Fuel consumption and $\mathrm{CO}_{2}$ emissions have grown $9.8 \%$ per year. In 2003, 251.8 million operations were done completing 26,214.5 million running kilometers at an average of $104.1 \mathrm{~km}$ per operation. The operation factor changed from $113.2 \mathrm{~km}$ per operation in 1997 to 104.1 in 2003 . The HDV used 6,553.6-9,175.1 million diesel liters (6.1-8.5 million tonnes oil equivalent) and emitted 17.5-24.6 million tonnes of $\mathrm{CO}_{2}$ equivalent. In 2003, the payload was 1850 million tonnes. In terms of tonne kilometers, there was a steady increment during last 6 years until 192,587 million tonne kilometers.

With a load capacity of 5.6 million tonnes, load factors of $80 \%$ and $40 \%$ (depending if empty running is excluded
Fig. 2 Road freight transport, DIs indicators by service and vehicle type (2003)
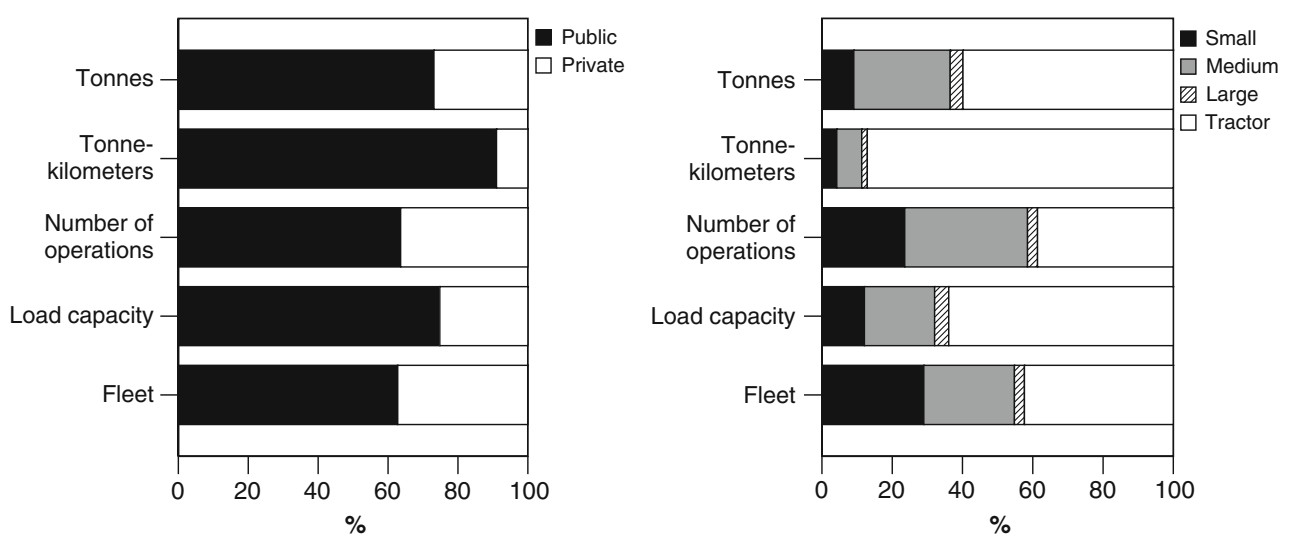
Table 2 Road freight transport, HDV indicators by service and vehicle type (2003)

\begin{tabular}{|c|c|c|c|c|c|c|c|}
\hline Type & $\begin{array}{l}\text { Indicator name } \\
\text { and units }\end{array}$ & Public Service & Private Service & $\begin{array}{l}\text { Small rigid } \\
(2 \text { axles })<10 t\end{array}$ & $\begin{array}{l}\text { Medium rigid } \\
\text { ( } 2 \text { axles) } 10-18 t\end{array}$ & $\begin{array}{l}\text { Large rigid } \\
(>2 \text { axles })>18 t\end{array}$ & Tractor \\
\hline DI & Fleet (number of vehicles $10^{3}$ ) & 211.0 & 125.4 & 97.5 & 86.7 & 9.6 & 142.5 \\
\hline DI & Load capacity $\left(10^{6} \mathrm{t}\right)$ & 4177.5 & 1408.0 & 675.1 & 1116.4 & 223.6 & 3571.1 \\
\hline DI & Operations $\left(10^{9}\right)$ & 160.2 & 91.6 & 59.3 & 88.0 & 7.1 & 97.3 \\
\hline DI & Tonnes $\left(10^{9} \mathrm{t}\right)$ & 1352.8 & 497.2 & 168.1 & 507.3 & 67.0 & 1108.1 \\
\hline DI & Tonne kilometres $\left(10^{9} \mathrm{tkm}\right)$ & 175.3 & 17.3 & 8.1 & 13.7 & 3.1 & 167.7 \\
\hline KPI & Vehicle loading-loaded (\%) & 81 & 79 & 65 & 82 & 82 & 83 \\
\hline KPI & Vehicle loading-total (\%) & 41 & 39 & 35 & 41 & 42 & 43 \\
\hline KPI & Empty running operations (\%) & 46 & 47 & 44 & 49 & 49 & 46 \\
\hline KPI & Empty running kilometers (\%) & 25 & 26 & 24 & 28 & 28 & 25 \\
\hline KPI & Vehicle time utilization (\%) & 82 & 75 & 81 & 79 & 71 & 78 \\
\hline
\end{tabular}

or not) indicated potential for improving the values based on the fact that some vehicles achieve higher load factors than others. Regarding empty running, $47 \%$ of operations and $26 \%$ of kilometers were done with empty vehicles showing the potential for enhancing the efficiency of delivery operations. Given the current demand patterns, the lowest attainable percentage of empty moves has not been reached yet. Vehicle time utilization had an average value of $79 \%$. This value is higher that the value presented by McKinnon [26], around 63\%, which excluded from the total vehicle hour utilization: the driver's rest period on the road, idle and undergoing maintenance and repairs. The genesis of the differences could be the high percentage of public service vehicles [14]; the vehicle is the main economic source of the company and does not depend on other economic activities.

In 2003, fuel and emission efficiency were 0.031$0.044 \mathrm{~kg}$ of oil equivalent per tonne kilometer and 91.1-

Table 3 Road freight transport, HDV performance data (1997-2003)

\begin{tabular}{|c|c|c|c|c|}
\hline Type & Indicator name and units & 1997 & 2003 & Annual increment $\left(\% y^{-1}\right)$ \\
\hline \multirow[t]{9}{*}{ DIs } & Fleet (number of vehicles $10^{3}$ ) & 234.3 & 336.3 & 7.3 \\
\hline & Load capacity $\left(10^{3} \mathrm{t}\right)$ & 3596.1 & 5586.0 & 9.2 \\
\hline & Operations $\left(10^{6}\right)$ & 145.7 & 251.8 & 12.1 \\
\hline & Running kilometers $\left(10^{6} \mathrm{~km}\right)$ & 16506.8 & 26214.5 & 9.8 \\
\hline & Tonnes $\left(10^{6} \mathrm{t}\right)$ & 1054.8 & 1850.0 & 12.6 \\
\hline & Tonne kilometres $\left(10^{9} \mathrm{tkm}\right)$ & 119.5 & 192.6 & 10.2 \\
\hline & Fuel consumption $\left(10^{6} 1\right)^{1}$ & $\begin{array}{l}4952.0 \pm 825.3 \\
(4126.7-5777.4)\end{array}$ & 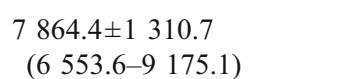 & 9.8 \\
\hline & Tonnes oil equivalent $\left(10^{6} \text { toe }\right)^{1}$ & $4.6 \pm 0.8(3.8-5.3)$ & $7.3 \pm 1.2(6.1-8.5)$ & 9.8 \\
\hline & $\begin{array}{l}\text { Tonnes of } \mathrm{CO}_{2} \text { equivalent } \\
\left(10^{6}+\mathrm{CO}_{2} \mathrm{e}\right)^{1}\end{array}$ & $13.3 \pm 2.2(11.0-15.5)$ & $21.0 \pm 3.5(17.5-24.6)$ & 9.8 \\
\hline \multirow[t]{11}{*}{ KPIs } & Vehicle loading-loaded operations (\%) & 79 & 80 & 0.2 \\
\hline & Vehicle loading-total operations (\%) & 41 & 40 & -0.4 \\
\hline & Operation factor ( $\mathrm{km} /$ operation) & 113.3 & 104.1 & -1.3 \\
\hline & Empty running operations (\%) & 47 & 47 & 2 \\
\hline & Empty running kilometers (\%) & 26 & 26 & -2 \\
\hline & Fuel efficiency (koe/t-km) ${ }^{1}$ & $0.038 \pm 0.006(0.032-0.045)$ & $0.038 \pm 0.006(0.031-0.044)$ & -0.2 \\
\hline & Emission efficiency $\left(\mathrm{grs} \mathrm{CO}_{2} / \mathrm{t}-\mathrm{km}\right)^{1}$ & $110.9 \pm 18.5(92.4-129.4)$ & $109.3 \pm 18.2(91.1-127.5)$ & -0.2 \\
\hline & Vehicle time utilization $(\%)$ & 78 & 79 & 0.2 \\
\hline & Transport content $(\mathrm{km} / \mathrm{t})$ & 15.6 & 14.2 & -1.6 \\
\hline & Transport distance $(\mathrm{km})$ & 113.2 & 104.1 & -1.3 \\
\hline & Transport efficiency (tkm/vkm) & 7.2 & 7.3 & 0.3 \\
\hline
\end{tabular}

${ }^{1}$ the values are means \pm standard deviations and ranges (in parenthesis)

${ }^{2}$ not significant differences 
$127.5 \mathrm{~g}$ of $\mathrm{CO}_{2}$ equivalent per tonne kilometer respectively. Compare to 1997 data, there was a small improvement of impact of transport operations on the environment during the studied period (Table 3). The improvement was due to technological development of new vehicles. Fuel and emission efficiency indicators were obtained relating the absolute indicators, fuel consumption in tonnes oil equivalent (toe) and tonnes of $\mathrm{CO}_{2}$ equivalent $\left(\mathrm{tCO}_{2} \mathrm{e}\right)$, to transport work expressed as tonne kilometers [29]. The fuel consumption is estimated from the running kilometers considering: an average consumption value of $0.25-0.351 / \mathrm{km}$ in 2003 and 1997 [26, 29, 30], and using the equivalences of 41.87 petajoules per mtoe and 38.66 megajoules per liter of diesel [31]. The $\mathrm{tCO}_{2} \mathrm{e}$ are directly estimated from the toe using the equivalence of 0.345 toe per $\mathrm{tCO}_{2} \mathrm{e}$ [31]. With the range of values, uncertainties of fuel and emission efficiencies were bounded and sensitivity analysis of the estimates could be calculated. Conversion equivalences are kept constant. Therefore, the fuel and emission efficiency values given in this paper are representative of mean conditions and must be used exclusively as reference values.

The aggregate Spain's trucking requires about 1.9 megajoules per tonne kilometer. This value is similar to the value reported by Steenhof [32] in Canada, 2.2 megajoules per tonne kilometer, and quite below the values shown in other studies and countries: 2.8 in EU-8 reported by Schipper [33], 2.9 in US by Pimentel [34] and 3.5 in Australia by Lenzen [35]. Consumption values of HDV followed a positive trend during last 30 years and depend on several factors: technology available at the moment, size of the vehicle, speed and driving conditions [30].

The comparison between the research outcomes of different European studies showed that the differences in energy and $\mathrm{CO}_{2}$ efficiency observed in road freight transport surveys are small. Leonardi [29] found a $\mathrm{CO}_{2}$ efficiency of $80.0 \mathrm{~g}$ of $\mathrm{CO}_{2}$ equivalent per tonne kilometer in Germany for 40 tonnes articulated trucks operating over long distances and with low intensity weights. Similarly, Beaumont [36] reported $92-155$ in UK for trucks over 40 tonnes and the Department for Transport in this country reported an efficiency of 82 for articulated trucks over 33 tonnes [20]. The Departments for Transport in Germany and France reported efficiencies around 100 [21, 22]. The paper explicitly includes all truck sizes above 6.0 Gross Vehicle Weight (GVW) and the figures 91.1-127.5 are slightly higher when comparing with the heaviest, long haul trucks in Europe. The emission values given in this study are higher than the emissions factor range for road freight vehicles of Van Wee, 45-100 grs $\mathrm{CO}_{2} / \mathrm{tkm}$ [37].

Transport content changed between 1997 and 2003 from $15.6 \mathrm{~km} /$ tonne in 1997 to 14.2 in 2003. Transport distance was 104.1 kilometers in 2003 and varied respect 1997 value (negative increment of $1.3 \%$ per year). Transport efficiency slightly increased during investigated period, 7.3 and 7.2 tonne kilometers per vehicle kilometers in 2003 and 1997. Transport distance declined because of an improvement in logistics and had a clear effect on transport content decline. However, improvement in logistics had no effect on empty running kilometers and empty running operations.

Table 4 shows important differences in DIs and KPIs according to logistical reach. Transport within municipalities and between municipalities transported 613.1 and $1,188.4$ million tonnes respectively $(5,542.2$ and $132,868.2$ million tonne kilometers). Oppositely, international transport had smaller values, 50.3 million tonnes and 54,177.2 million tonne kilometers. Transport content varied from 1.4 to $71.5 \mathrm{~km}$ per tonne. By using this indicator, Böge [38] has computed that a pot of $150 \mathrm{~g}$ of strawberry yoghurt sold in Germany travels $9.2 \mathrm{~m}$, giving a transport content of $61 \mathrm{~km}$ per tonne. The transport content can be used to compare different transports and tracking the development of a product's transport content can exhibit a historical development in logistics [25]. Transport distance within municipalities, between municipalities and international transport, was $9,111.8$ and $1,083.5 \mathrm{~km}$ respectively. International transport showed the highest rate of transport efficiency, 15.2 tonne kilometers per vehicle kilometers.

\subsection{Transport distance and elasticities}

Figure 3 shows the curves obtained when regressing transport distance against transport content and transport efficiency. An increase in transport content can both be due to sourcing and marketing in a wider area, increase in transport distance, and to a more inefficient transport. The relationship between transport efficiency and transport distance is constant. Transport efficiency increases proportionally to transport distance increases, because of the possibility to increase vehicle loading and use of bigger vehicles. Transport distance explained a large percentage of the variability of transport efficiency (99\%).

As transport distance increases, transport content grows together with transport efficiency but at a different rate. The impact of transport distance on transport content is much bigger than the impact on transport efficiency. For instance, if transport distance increases from $112 \mathrm{~km}$ to $1,084 \mathrm{~km}$ ( $868 \%$ increment) at the same time transport content increases from 14.3 to $71.5(400 \%)$ and transport efficiency increases from 7.8 to 15.2 (95\%). Consequently, the improvement of transport efficiency is small compare with the disadvantage of traveling longer distances.

Elasticity values indicate the sensitivity of a dependent variable due to a given rate of change in the independent variable. The calculation of road freight transportation elasticities has been widely discussed [39, 40]. Figure 3 shows the overall elasticity of transport efficiency and 
Table 4 Road freight transport, HDV indicators by reach (2003)

\begin{tabular}{llr}
\hline Logistical reach & Indicator & $\mathbf{2 0 0 3}$ \\
\hline Within municipalities & Tonnes $\left(10^{6} \mathrm{t}\right)$ & 613.1 \\
& Tonne kilometres $\left(10^{6} \mathrm{tkm}\right)$ & 542.2 \\
& Operations $\left(10^{3}\right)$ & $92,000.1$ \\
& Running kilometers $\left(10^{6} \mathrm{~km}\right)$ & 831.8 \\
& Transport content $(\mathrm{km} / \mathrm{t})$ & 1.4 \\
& Transport distance $(\mathrm{km})$ & 9.0 \\
& Transport efficiency $(\mathrm{tkm} / \mathrm{vkm})$ & 6.7 \\
Between municipalities & Tonnes $\left(10^{6} \mathrm{t}\right)$ & $1,188.4$ \\
& Tonne kilometres $\left(10^{6} \mathrm{tkm}\right)$ & $132,868.2$ \\
& Operations $\left(10^{3}\right)$ & $152,000.1$ \\
& Running kilometers $\left(10^{6} \mathrm{~km}\right)$ & $16,999.9$ \\
& Transport content $(\mathrm{km} / \mathrm{t})$ & 14.3 \\
& Transport distance $(\mathrm{km})$ & 111.8 \\
& Transport efficiency $(\mathrm{tkm} / \mathrm{vkm})$ & 7.8 \\
& Tonnes $\left(10^{6} \mathrm{t}\right)$ & 50.3 \\
& Tonne kilometres $\left(10^{6} \mathrm{tkm}\right)$ & $54,177.2$
\end{tabular}

transport content with respect to transport distance; the elasticity values are associated with the regression equations. Transport efficiency elasticity is between 0.01 and 0.63 , indicating that a $10 \%$ increase in transport distance increases transport efficiency by between $0.1 \%$ and $6.3 \%$. Similarly, transport content elasticity is between 0.99 and 0.37 and a $10 \%$ increase in transport distance increases transport content by $9.9 \%$ and $3.7 \%$.

Figure 3 shows a plot of transport efficiency elasticity and transport content elasticity against transport distance. Transport efficiency elasticity is smaller at short dis- tances and become asymptotic beyond longer distances. Short distances influence transport efficiency less than long distances. Oppositely, transport content elasticity is bigger at short distances and become asymptotic beyond longer distances. Transport distances of $83 \%$ of total vehicle kilometers, $72 \%$ of total tonne kilometers, $97 \%$ of total tonnes and $98 \%$ of total operations, are in the range of 9-112 kilometers. In this range the implication is that even a small increase in transport distance of road freight transport can bring about an important increase in transport content.
Fig. 3 Impact of transport distance on transport efficiency and transport content, and elasticities (2003)
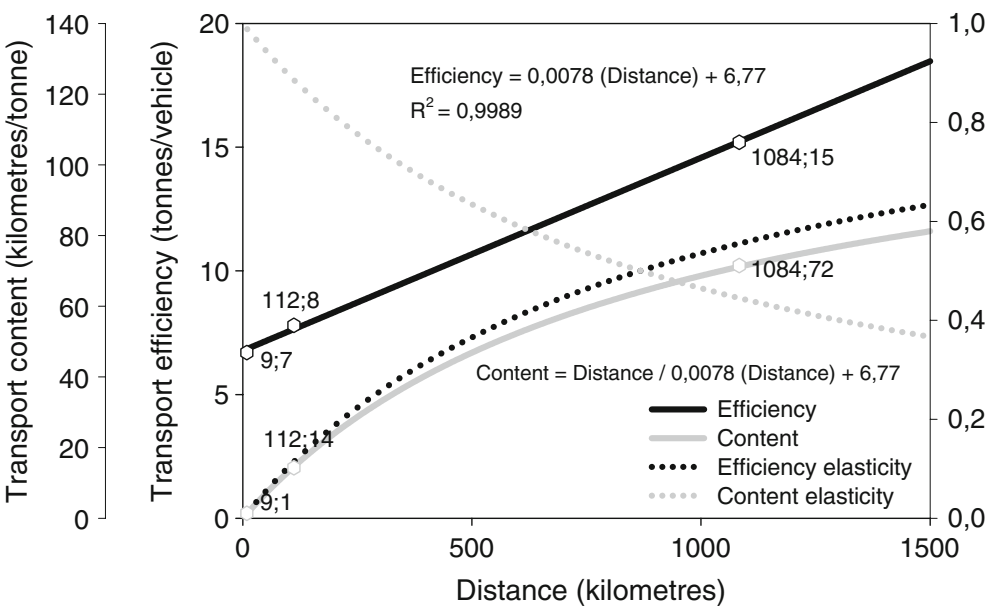

0,8

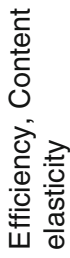




\section{Conclusions}

This study describes road freight transport in Spain: utilization, productivity and efficiency, using the PRFSS and a standard set of descriptive and key performance indicators. The study makes a benchmarking of transport and shows that absolute values have grown during period 1997-2003; relative values of vehicle utilization, productivity and energy intensity have not grown. Consequently, transport efficiency has been poorly implemented. The study finds that mean fuel and emission efficiency values in 2003, $0.038 \mathrm{koe} / \mathrm{tkm}$ and 109.3 grs $\mathrm{CO}_{2} / \mathrm{tkm}$, show a small improvement respect to 1997 values.

A comparison of energy and $\mathrm{CO}_{2}$ emission efficiency indicators for other European countries was given in this study since the information was developed in a common basis across European countries according with Eurostat's recommendations. The review showed that there were no big differences between studies and countries.

The PRFSS includes intramunicipal data to have a better understanding of urban freight activities in a first estimate (light duty vehicles LDV are not included in the survey). Opposite to the international transport, transport within municipalities, with a share of one third of tonnes, produces less than $5 \%$ of running kilometers and $3 \%$ of tonne kilometers. Urban freight activities are not exclusively based on small rigid vehicles, because they carry less than $10 \%$ of total tonnes, and need the support of medium rigid vehicles. There is private service dominance in short distances using small and medium rigid vehicles. Opposite, there is public service dominance in longer distances using higher capacity vehicles.

The international transport, even though is more efficient than the national transport, produces higher environmental impacts because of longer distances. Short and medium distances, 9-112 km, are critical as small increments within this distance range produce high increments on transport content and therefore high environmental impacts.

\section{Discussion and recommendations}

The age of the trucks is a key parameter in determining truck energy efficiency and emissions [41]. Even though no consideration was given to the age of the trucks, the age of rigid vehicles decreased from 8.6 to 6 years (similarly to tractors from 5.7 to 4.7). Consequently, little technological and organizational improvements are identified. Fuel and emission efficiency values have remained almost constant and the potential benefits of technological innovations were not used to satisfy public interest (reduced greenhouse gas emissions and oil imports) [42]. There is need of new advanced technologies that have the potential to improve fuel economy and emissions characteristics of new HDV [43]. An important policy question is how and to what extent future efficiency innovations might be directed to the public interest [44].

The low transport efficiency values can be attributed, to a large extent, to strategies such as supply chain management and "just in time deliveries" of freight loads. Smaller but more frequent loads are delivered exactly when needed, leaving less room to optimize efficiency load factors [45]. While more efficient loading generally leads to economic savings, these could be outweighed by costs involved in achieving the efficiency gains, such as costs of storage [11]. It is not easy to improve transport efficiency directly, for this is mainly the result of market-driven forces like price and availability of transport [33]. There are few points that can be influenced by the managers of trucking companies as the choice of the vehicle type and the implementation of intelligent transportation scheduling systems (ITSS) [44, 46].

Though important for the economy, road freight creates certain external costs: accidents, emissions, noise and unrecovered costs associated with the provision, operation, and maintenance of public facilities. Forkenbrock estimated these external costs in 0.55 cent per tkm, equal to $13.2 \%$ of the private operating cost of intercity road freight transportation [47, 48]. In the case of road freight transport, internalizing these external costs will lead to some reduction in energy consumption and $\mathrm{CO}_{2}$ emissions of transportation services, such as locating producing facilities closer to markets. Making transport users pay for the full external costs of the transport activity could provide an incentive to improve transport efficiency and reduce environmental impacts. The real problem related to transport external costs is who is able to internalize them and who wants to do that.

This study highlights differences on transport content related to transport distances and gives managers an incentive to raise operating performance by reducing energy consumption, vehicle kilometers and yielding environmental benefits. Nevertheless, the results are clearly influenced by the definition of content and efficiency indicators. For transport content the kilometers appear in the numerator, while for transport efficiency the kilometers appear in the numerator and denominator. Therefore, transport content will be more influenced by distance given these definitions. Similarly, the results draw attention to the peripheral situation of Spain, and the international transport with less than $3 \%$ of total tonnes produces $18 \%$ of running kilometers and $28 \%$ of tonne kilometers. Consequently, demand and supply determine distances and, in many cases, there are no possibilities to minimize transport distances.

Future PRFSS editions have to perform a depth analysis of productivity and efficiency indices in order to give light 
on the causes of the differences in KPIs. This intensive work needs a high level of cooperation from the participating companies. Future surveys have to examine more KPIs and study further relationships between transport and logistical variables, besides interrelationships between KPIs. Expand sample size permits a greater segmentation, more number of homogeneous strata, improving the accuracy.

The KPIs used in this study are expressed, directly or indirectly, in terms of tonne kilometers. There are intrinsic limitations based on a truck reaching the maximum weight, as a truck might be filled without reaching the maximum weight. This could impact some of the indicators and especially create biases for some commodities. For instance, food is a relatively low-density product and loads moved by truck tend to be volume-constrained rather than weight-constrained [26]. Commodity proved to have a significant effect on emission efficiency, with commodity groups composed of finished or semi finished products having much lower commodity emission efficiencies than those of raw materials [49]. Increasing freight transport could be related with a shift in economic output towards processed, manufactured goods (away from traditional resource orientation) and subsequently more goods are being moved for production processes and consumption decreasing emission efficiency. Could be interesting to calculate KPIs making distinction in the nature of the product and/or express KPIs in terms of volume units instead of weight units.

Although the study indicates a focus on energy and environmental efficiency, operational requirements of shippers and carriers must be taken into account (i.e. the increased trade of manufactured goods together with the emergence of "just in time deliveries" could impact emission efficiency). The selection of KPIs for the study excludes any reference to the costs of transport operations. Consequently, the KPIs were not designed to measure the commercial performance, as few companies would be prepared to divulge the costs of transport operations.

\section{References}

1. Pérez-Martínez PJ, Otero-Pastor I (2006) Environment and transport indicator system in Spain. Are we tending towards sustainability? Conference proceedings of environment and transport. INRETS, Reims, France, pp 60-65

2. Pérez-Martínez P, Monzón de Cáceres A (2005) Informe sobre transporte y medio ambiente. Trama 2005. Centro de Publicaciones Secretaría General Técnica Ministerio de Medio Ambiente, Madrid, Spain

3. Koopmanm GJ (1997) Long-term challenges for inland transport in the European Union: 1997-2010. Energy Policy 25:1151-1161
4. Schipper L, Unander F, Murtishaw S, Ting M (2001) Indicators of energy use and carbon emissions: explaining the energy economy link. Annu Rev Energy Environ 26:49-81

5. McKinnon AC (2003) Logistics and the environment. In: Henscher DA, Button KJ (eds) Handbook of transport and the environment. Elsevier, Amsterdam, pp 665-685

6. McKinnon AC (2008) $\mathrm{CO}_{2}$ emissions from freight transport in the UK. Report prepared for the climate change working group for the commission for integrated transport. Logistics Research Centre, Heriot-Watt University, Edinburgh

7. Kamakaté F, Schipper L (2008) Trends in truck freight energy use and carbon emissions in selected OECD countries from 1973 to 2003. Washington D.C.: 87 th Annual meeting of the transportation research board

8. OECD (2003) Organisation of economic cooperation and development, environment directorate. Analysis of the links between transport and economic growth, Paris, France

9. OECD (2007) Organisation of economic cooperation and development, environment directorate. Project on decoupling transport impacts and economic growth, Paris, France

10. ECMT (2007) European Conference of Ministers of Transport. Cutting Transport $\mathrm{CO}_{2}$ emissions: what progress? OECD, Paris, France

11. EEA (2006) European environmental agency. Transport and environment: facing a dilemma. TERM 2005: indicators for tracking transport and environment in the European Union, Copenhagen, Denmark

12. McKinnon AC, Leonardi J (2008) The collection of long distance road freight data in Europe. Annecy: 8th International conference on survey methods in transport, harmonization and data comparability

13. Binnenbruck HH (2008) The acquisition of long distance freight data. Annecy: 8th International conference on survey methods in transport, harmonization and data comparability

14. Secretaria General Técnica (2005) Ministerio de Fomento. Los transportes y los servicios postales. Informe anual 2004. Centro de Publicaciones, Secretaría General Técnica Ministerio de Fomento, Madrid, Spain

15. Aparicio F, Burón JM, Páez FJ, López JM, Alegre JA, Gómez A, Arenas B, López I, Izquierdo O, Galán P (2005) Impacto del Transporte de mercancías sobre el medio ambiente, y el consumo energético. Estud Constr Transp 103:63-96

16. Ministerio de la Presidencia (2004) Real Decreto 1866/2004, de 6 de septiembre, por el que se aprueba el Plan nacional de asignación de derechos de emisión, 2005-200. Boletín Oficial del Estado 216:30616-30642

17. Secretaria General Técnica (2003) Ministerio de Fomento. Encuesta permanente de transporte de mercancías por carretera 2003. Centro de Publicaciones, Secretaría General Técnica Ministerio de Fomento, Madrid

18. Pasi S (2008) Harmonization and comparability of European Union road freight statistics. Annecy: 8th International conference on survey methods in transport, harmonization and data comparability

19. Pasi S (2007) Trends in road freight transport 1999-2005. Transport statistic in focus. Eurostat, Office for Official Publications of the European Communities, Luxemburg

20. DFT (2007) UK Department for Transport. Road freight statistics (2006) Transport statistics bulletin. DFT, London

21. MTETM/SESP (2006) Ministère des Transports de l'Equipement, $\mathrm{du}$ Tourisme et de la Mer/Service économie statistiques et prospective. Les comptes des transports en 2005. Premiers résultats, Paris

22. KBA (2006) Kraftfahrt-Bundesamt. Bundesamt für Güterverkehr. Statistische Mitteilungen, Reihe 8: Kraftverkehr, Güterkraftverkehr deutscher Lastkraftfahrzeuge, Sonderheft 2, Jahr 2005, Berlin 
23. Rebollo Rivelott MD, Cuesta Rilo L (2000) La encuesta de transporte de mercancías por carretera. Fuentes Estad 47:13-14

24. SAS Institute (1999) SAS/STAT user's guide, version 8. SAS Institute Inc, Cary, NC

25. Nielsen DL, Jespersen PH, Petersen T, Hansen LG (2003) Freight transport growth: a theoretical and methodological framework. Eur J Oper Res 144:295-305

26. McKinnon AC, Ge Y (2004) Use of a synchronized vehicle audit to determine opportunities for improving transport efficiency in a supply chain. Int J Logist 7:219-238

27. Caplice C, Sheffi Y (1994) A review and evaluation of logistics metrics. Int J Logist Manag 5:11-28

28. Roth A, Kaberger T (2002) Making transport systems sustainable. J Clean Prod 10:361-371

29. Léonardi J, Baumgartner $\mathrm{M}$ (2004) $\mathrm{CO}_{2}$ efficiency in road freight transportation: Status quo, measures and potential. Transp Res Part D 9:451-464

30. Mataix C, Acebrón F (2006) Fabricantes y reducción de emisiones. Semana Europea de la Movilidad. Planes de movilidad urbana y tecnologías de reducción de emisiones en el transporte. Centro de Publicaciones Secretaría General Técnica Ministerio de Medio Ambiente, Madrid, Spain, pp $142-150$

31. IEA (2004) International energy agency. World energy outlook 2004 (Complete Edition-ISBN 9264108173). OECD Energy 2004(22):i-576

32. Steenhof P, Woudsma C, Sparling E (2006) Greenhouse gas emissions and the surface transport of freight in Canada. Transp Res Part D 11:369-376

33. Schipper L, Scholl L, Price L (1997) Energy use and carbon emissions from freight in 10 industrialized countries: an analysis of trends from 1973 to 1992 . Transp Res Part D 2:57-76

34. Pimentel D, Pleasant J, Barron J, Gaudioso N, Pollock E, Chae Y, Kim A, Lassiter C, Schiavoni A, Jackson M, Eaton A (2004) US energy conservation and efficiency: benefits and costs. Environment, Development and Sustainability 6:279-305

35. Lenzen M (1999) Total requirements of energy and greenhouse gases for Australian transport. Transp Res Part D 4:265-290

36. Beaumont, L (2004) Key Performance Indicators for the Pallet Distribution Network sector. Freight Best Practice Report, www. freightbestpractice.org.uk, Birmingham, UK

37. Van Wee B, Janse P, Van Den Brink R (2005) Comparing energy use and environmental performance of land transport modes. Transp Rev 25:3-24
38. Böge S (1995) The well-travelled yoghurt pot: lessons for new freight transport policies and regional production. World transport-Policy \& Practice 1:7-11

39. Beuthe M, Jourquin B, Geerts JF, Koul C, Ha N (2001) Freight transportation demand elasticities: a geographic multimodal transportation network analysis. Transp Res Part E 37:253-266

40. Abdelwahab WM (1998) Elasticities of mode choice probabilities and market elasticities of demand: evidence from a simultaneous mode choice/shipment-size freight transport model. Transport Research Part E 34:257-266

41. Santini DJ, Vyas AD (2005) Introduction of hybrid and diesel vehicles. Status within the life cycle of technology adoption. In transportation research record: journal of the transportation research board, No. 1941. TRB, National Research Council, Washington, D.C., pp 18-25

42. Saricks C, Vyas AD, Stodolsky F, Maples JD (2003) Fuel consumption of heavy-duty trucks: potential effect of future technologies for improving energy efficiency and emissions. In transportation research record: journal of the transportation research board, No. 1842, TRB. National Research Council, Washington, D.C, pp 9-19

43. Lutsey N, Sperling D (2005) Energy efficiency, fuel economy, and policy implications. In transportation research record: journal of the transportation research board, No. 1941, TRB. National Research Council, Washington, D.C, pp 8-17

44. Ang-Olson J, Schroeer W (2002) Energy efficiency strategies for freight trucking. In transportation research record: journal of the transportation research board, No. 1815, TRB. National Research Council, Washington, D.C, pp 11-18

45. Browne M, Rizet C, Anderson S, Allen J, Keita B (2005) Life cycle assessment in the supply chain: a review and case study. Transp Rev 25(6):761-782

46. Baumgartner M, Leonardi J (2008) Improving computerized routing and scheduling and vehicle telematics. A qualitive survey. Transp Res Part D 13:377-382

47. Forkenbrock DJ (1999) External costs of intercity truck freight transportation. Transp Res Part A 33:505-526

48. Forkenbrock DJ (2001) Comparison of external costs of rail and truck freight transportation. Transp Res Part A 35:321-337

49. Vanek FM, Morlok EK (1998) Freight energy use disaggregated by commodity. Comparisons and discussion. In Transportation Research Record: Journal of the Transportation Research Board, No. 1641, TRB. National Research Council, Washington, D.C., pp $3-8$ 